\title{
PREPARATION OF FISH BURGER FROM PANGUS CATFISH (Pangasius sutchi) AND EVALUATION OF QUALITY AND SHELFLIFE DURING DIFFERENT STORAGE CONDITIONS
}

\author{
M. A. Ejaz, F. H. Shikha and M. I. Hossain* \\ Department of Fisheries Technology, Bangladesh Agricultural University \\ Mymensingh-2202, Bangladesh
}

\begin{abstract}
Improved fish burger was developed from pangus fish (Pangasius sutchi) by using different kinds of food additives ( $25 \%$ mashed potato, $2 \% \mathrm{NaCl}, 2 \%$ oil, $2 \%$ spices such as onion, ginger, garlic, green chili, hot spices and $0.6 \%$ sugar). Proximate composition and sensory, chemical and microbiological changes of pangus fish burger were determined to evaluate the shelf life and storage stability kept at room $\left(28^{\circ} \mathrm{C}\right)$ and refrigeration $\left(5^{\circ} \mathrm{C}\right)$ temperature. It was observed that, the moisture, $\mathrm{pH}$ and protein contents in pangus burger were decreased than that of fish mince. On the other hand, lipid and ash contents were higher. Among the variable levels of mashed potato level, 25\% mashed potato level showed the best sensory performance and was recommended for the commercial production. At room temperature, the sensory attributes deceased significantly $(\mathrm{P}<0.05)$ throughout the storage period. On the other hand, at refrigerated temperature $\left(5^{\circ} \mathrm{C}\right)$ the product was more stable. The TVB-N value increased progressively throughout the storage period $(\mathrm{P}<0.05)$ at both room $\left(28^{\circ} \mathrm{C}\right)$ and refrigerated $\left(5^{\circ} \mathrm{C}\right)$ temperature. The microbial load was also increased significantly $(\mathrm{P}<0.05)$ at both temperatures but the growth pattern was slower at refrigeration temperature. After considering all the results, it was concluded that, the shelf life of pangus fish burger was very short, in fact not more than 24 hours at $28^{\circ} \mathrm{C}$. On the other hand at $5^{\circ} \mathrm{C}$ pangus fish burger may remain in good condition up to 72 hours.
\end{abstract}

Key words : Food additives, Room temperature, Refrigeration temperature, TVB-N value, Bacterial load

\section{INTRODUCTION}

It is well known that fish flesh has some unique characteristics as having high protein content with balanced profile of amino acids, polyunsaturated and essential fatty acids with $\omega-3$ series of fatty acids and low level of harmful cholesterol and saturated fat (Edwards and Kaewpaitoon, 1981). Due to increasing awareness of the consumers on health issues, consumption of fish and fishery products are increasing day by day. At

* Correspondence E-mail :- ihossain1968@hotmail.com 
present context, value-added fish minced products will bring immediate benefit to the existing fish processing industries of the country (Nowsad et al., 1994).

One of the important mince based product is fish burger. Fish burger is a popular and tasty item in fast food industry. In recent years, the preference of the consumers has significantly directed towards the fast food consumption since there has been a rapid urbanization and an increase in working women population. The working people along with new generation students and young people are now more interested on fast foods. During the last 5 years, a lot of fast-food shops have been opened in city, suburb and industrial areas of the country. There have been many studies about the production and quality stability of the fishery fast food products including fish cake, fish crackers, fish balls and fish burgers (Ihm et al., 1992a; Ihm et al., 1992b). Unfortunately, although burgers prepared from beef and poultry are served to the fast-food shops in the market, fish burgers are not produced commercially in Bangladesh. Earlier, a noble initiative was taken to produce fish burger from low-cost silver carp and sea catfish (Nowsad et al., 2004). However, except some initiative, production at commercial level would not have been possible due to lack of entrepreneurship in that time.

Pangus catfish, commonly known as Thai pangus (Pangasius sutchi), a low-priced fish in the common fish market, would serve as an adequate source of raw material for fish burger that may provide a good taste and nutrition to the young and outgoing people in cheaper price.

Considering the above facts, the present study was therefore, designed and conducted to formulate and prepare fish burger from Thai pangus (Pangasius sutchi) for better utilization of this low priced species and to investigate the shelf life of fish burger during different storage conditions.

\section{MATERIALS AND METHODS}

\section{Collection of fish species}

Fresh Thai pangus was collected from the fishermen of Bailor union. It is because the later part of this project was to introduce them with the new technology and to improve their livelihood by value addition. Immediately after collection, the fish was preserved properly with crushed ice in an insulated box (Cosmos Ltd., Seol, Korea, $20 \mathrm{~kg}$ capacity) and transported to the laboratory of the Faculty of Fisheries, Bangladesh Agricultural University. The average size of the fish was $48 \pm 2.50 \mathrm{~cm}$ and $1.60 \pm 0.35 \mathrm{~kg}$.

\section{Preparation of the product}

The preparation of the fish burger was divided into two steps. First, preparation of fish mince from the raw fish and then preparation of fish burger from the prepared mince. The steps are described as bellow: 


\section{Preparation of the mince from the fish species}

The fishes were weighed and then washed with clean water, beheaded, eviscerated, skinned and washed. The skinned fishes were filleted and deboned manually in iced condition. Then the mince was prepared by a mechanical mincer (National Meat Grinder, MK-G3NS, Matsushita Electric Industrial Co. Ltd., Osaka, Japan.) through a 1mm orifice diameter so that all bones and connective tissues were removed from the muscles. All the utensils used in the experiment were cleaned with adequate washing and kept $\operatorname{cool}\left(5^{\circ} \mathrm{C}\right)$. Mince recovery from each fish was recorded. Crushed ice was made available through an ice maker (Lab Tech Ice Macker, Series Lcm - 200m, R4044A, UK) to maintain adequate temperature throughout the product preparation. The mince after mincing, was kept in a small bowl that is fixed in a big plastic bowl around which huge amount of ice was kept. Scheme for the preparation of fish mince from the fish species is presented in Fig. 1.

\section{Preparation of the fish burger from the mince}

The mince obtained from the pangus fish muscle was ground with $2 \% \mathrm{NaCl}, 2 \%$ oil, $0.6 \%$ sugar, $2 \%$ spices (onion, garlic, ginger, green chili paste and hot spices) and variable levels $(0,10,15,20$ and $25 \%)$ of mashed potato (Table 1 and 2). The mixing was done generally for 5-7 minutes. The whole dough was stuffed into a steel frame. The size of each burger patty was $(6.5 \times 6 \times 0.5 \mathrm{~cm})$. The steel frame was set on a wooden plate. Another wooden plate was fixed on the frame and held tightly with nuts and bolts to compress the material kept in the steel frame in between the two wooden plates. The material in between the wooden plate was frozen at $-20^{\circ} \mathrm{C}$ for 24 hours. After freezing, the patties were separated from the steel frame and dipped in a batter formulation (Table 3). Then it was fried in dip-oil. After cooling, the burger patties were packaged in air tight polyethylene bag for quality tests. Scheme for the preparation of burger from the fish mince is presented in Fig. 2.

Table 1. Ingredients and their percentages used for the preparation of burger

\begin{tabular}{lc}
\hline \multicolumn{1}{c|}{ Ingredient } & Percentage (\%) \\
\hline Mashed potato & $0,10,15,20,25$ \\
Salt $(\mathrm{NaCl})$ & 2 \\
Oil & 2 \\
Sugar & 0.6 \\
Spices (onion, garlic, ginger, green chili paste, hot spices) & 2 \\
\hline
\end{tabular}

An attractive looking, very good textured, excellent coloured, nice flavoured and tasty fish burger was developed from pangus fish mince using local gel enhancing ingredients and spices. Emphasis was given to add to the products a known taste so that the products could attract local consumer's acceptance. The list of the ingredients used for burger preparation and their percentages are shown in Table 1, 2 and 3.

The mashed potato in variable levels was used in order to determine the effect of mashed potato on the quality of the product. 


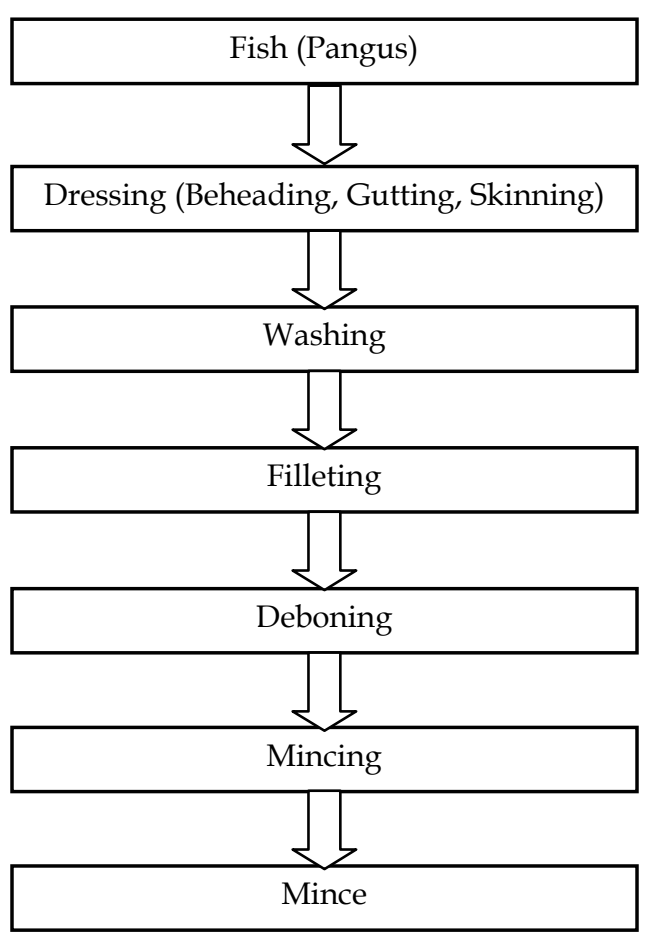

Fig. 1. Flow chart for preparation of buger from the mince

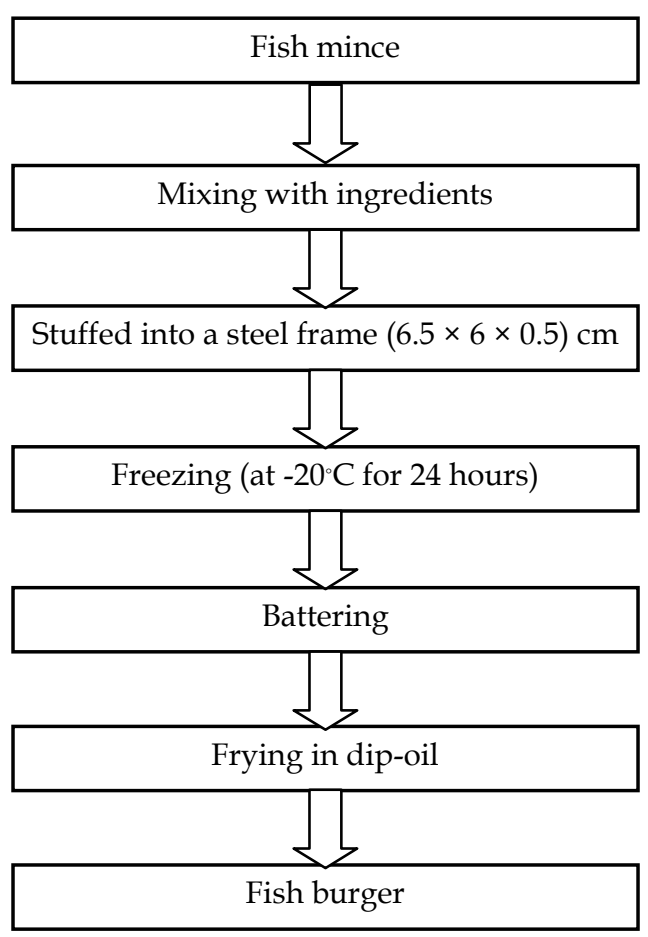

Fig. 2. Scheme for preparation of fish mince by mechanical mincer

Table 2. Spices and their percentages used for the preparation of burger

\begin{tabular}{l|c}
\hline \multicolumn{1}{c|}{ Spices } & Percentage (\%) out of 2\% of all spices \\
\hline Garlic powder & 20 \\
Onion powder & 20 \\
Ginger powder & 15 \\
Green chili paste & 10 \\
Mixture of hot spices & 35 \\
\hline
\end{tabular}

Table 3. Ingredients and their percentages used for the batter formulation for burger

\begin{tabular}{l|c}
\hline \multicolumn{1}{c|}{ Ingredient } & Percentage (\%) \\
\hline Wheat flour & 34.0 \\
Salt $(\mathrm{NaCl})$ & 1.0 \\
Monosodium glutamate & 1.0 \\
Spices (green pepper, ginger, garlic, cumin, onion paste) & 1.0 \\
Egg & 19.0 \\
Water & 44.0 \\
\hline
\end{tabular}




\section{Quality analysis}

The quality of the burger was analyzed by sensory and chemical analysis.

\section{Sensory evaluation}

A panel of nine-person including students, teachers and staffs of the Department of Fisheries Technology provided the sensory assessments of the products (Nowsad et al., 2000c). Prior to testing, panelists were familiarized with the properties of meat gel and the instructions relating to the scoring of the sample. Pretests were under taken with selected samples to familiarize the panelists with the measurement procedure. Three discs of gel $(0.5 \mathrm{~cm}$ thick) were supplied to each panelist to recognize every attribute. For softness/firmness the quality was evaluated by the numerical scores up to 10 , where for $\mathrm{S} / \mathrm{F}, 1=$ very soft; $10=$ extremely firm and for $\mathrm{C} / \mathrm{R}, 1=$ not chewy $/$ rubbery; $10=$ extremely chewy/rubbery and for colour and flavour scores used were from the range of 10 to1; where 10 = desired colour and flavour; 1 = absent of colour and flavour.

\section{Chemical evaluation}

$\mathrm{pH}$ at room temperature was determined for the homogeneous mixtures of samples and distillated water $(1: 10, \mathrm{w} / \mathrm{v})$ using a digital Mettler Toledo $\mathrm{pH}$ meter.

Proximate composition of fish mince and fish burgers in triplicates were determined as crude protein (AOAC, 1990), crude fat (Bligh and Dyer, 1959), crude ash (AOAC, 1990), moisture (Ludorff and Meyer, 1973). In crude protein estimation, about $1 \mathrm{~g}$ of comminuted sample was employed for Kjeldahl procedure. Lipid content was determined by extracting a given quantity of sample with acetone in Soxhlet Apparatus for 16 to 18 hours. Moisture content was determined by drying a $5 \mathrm{~g}$ sample in an oven at $105^{\circ} \mathrm{C}$ for 24 hours. Ash content was determined by igniting the sample in a muffle furnace at $550^{\circ} \mathrm{C}$ for 6 hours.

\section{Shelflife analysis}

Pangus fish burgers prepared with $25 \%$ mashed potato were stored at $5{ }^{\circ} \mathrm{C}$ and $28^{\circ} \mathrm{C}$ subsequently. Shelf life of the stored products was assessed by the determination of microbial load, chemical and sensory characteristics. Data was taken at the intervals of 24 hours.

\section{Sensory evaluation}

For the determination of sensory quality of the fish burgers scoring test was used (Paulus et al., 1979). All burgers were served to 11 panelists to evaluate the sensory attributes (colour, odour, taste, texture, general acceptability) of the samples by using 9-points descriptive scale. According to the scoring table, scores between 7-9 indicated 'high quality', scores between 4-6 indicated moderate quality' and scores between 1- 3 indicated the limit of 'unacceptability'. 


\section{Microbial analysis}

Aerobic plate count was done by spread plate count method. Peptone diluent $(0.2 \%)$ and plate count agar of commercial preparations or prepared in the laboratory as per method given in Cowan and Steel's Manual for the Identification of Medical Bacteria (edited by Barraw and Feltheam, 1993) were used in the shelf life study of fish burger.

\section{Chemical evaluation}

For chemical evaluation of shelflife TVB-N (Total Volatile Base Nitrogen) test was used. Total Volatile Base Nitrogen (TVB-N) was determined according to the methods given in AOAC (1984) with certain modification.

\section{Statistical analysis}

One-way analysis of variance and the general linear model using Windows for SPSS 9.0 were used to analyze the data. The Duncan's New Multiple Range Test (DMRT) was used to find the significant differences between storage periods.

\section{RESULTS AND DISCUSSION}

\section{Evaluation of the quality of the burger}

\section{Proximate composition analyses and $\mathrm{pH}$ measurement}

The proximate composition analyses and $\mathrm{pH}$ measurement of the fish burger are presented in Table 4 . The moisture content in fish burger was decreased; this might be resulted from release of water-drip during cooking. Protein content was also reduced, might be due to excessive heat generated during cooking that denatured the protein and/or burned into ash. On the other hand, lipid and ash contents were increased, which were the results of cooking of products in oil.

Table 4. Proximate composition and $\mathrm{pH}$ value of fish burger prepared from pangus catfish

\begin{tabular}{l|c|c|c|c|c}
\hline \multirow{2}{*}{ Type of product } & \multicolumn{4}{|c|}{ Proximate composition } & \multirow{2}{*}{$\mathrm{pH}$} \\
\cline { 2 - 5 } & Protein & Lipid & Ash & Moisture & \\
\hline Mince & $23.01 \pm 0.44$ & $4.89 \pm 0.13$ & $2.01 \pm 0.19$ & $70.15 \pm 1.16$ & $6.8 \pm 0.11$ \\
Burger & $20.98 \pm 0.57$ & $6.82 \pm 0.15$ & $2.98 \pm 0.09$ & $68.95 \pm 0.89$ & $6.6 \pm 0.05$ \\
\hline
\end{tabular}

* mean value \pm standard deviation of 3 individual measurements

Ihm et al. (1992a) determined that the protein and moisture rates of sardine burgers were lower than the rates of sardine as the raw material but increase in fat and ash contents was found in sardine burgers. These results of sardine burgers are in good agreement with the results of present study.

Azad (2001) also found that the protein and moisture content in fish burger decreased and lipid and ash content increased, which is very similar with the present study. 
The $\mathrm{pH}$ of the mince was about to neutral because of the pre-rigor prime quality fresh fish were used. The $\mathrm{pH}$ is a determining factor in the mince for higher gel forming ability. A good quality product can be prepared from the mince with around neutral $\mathrm{pH}$ (Azad, 2001). Although a slight decrease in $\mathrm{pH}$ in the pangus burger was observed (Table 4).

\section{Sensory evaluation}

Changes in scoring of the sensory attributes of pangus burger of variable mashed potato levels are shown in Table 5. The burger was prepared using mashed potato levels of 0,10 , $15 \%, 20$ and $25 \%$ of the mince. Among them, 25\% mashed potato level showed better sensory attributes and mouth feel. Result of the statistical analysis showed that, there were significant differences $(\mathrm{P}<0.05)$ between $\mathrm{S} / \mathrm{F}, \mathrm{C} / \mathrm{R}$, colour, flavour properties of burger. Although, at 10, 15 and 15, 20 and 25\% mashed potato level the C/R and colour showed no significant differences $(\mathrm{P}>0.05)$. The $25 \%$ mashed potato level showed higher performances among the five treatments. Considering all the sensory attributes and profitability factor, the $25 \%$ mashed potato level can be recommended for the commercial production of burger (Table 5).

Table 5. Effect of the mashed potato on sensory quality attributes of fish burger prepared from pangus fish mince (The description of the sensory scores is mentioned in materials and methods under the section quality analysis and sub section sensory evaluation)

\begin{tabular}{c|c|c|c|c|c|c}
\hline $\begin{array}{c}\text { Mashed potato } \\
\text { level (\%) }\end{array}$ & S/F1 & C/R & Colour & Flavour & FT $^{1}$ & GA $^{1}$ \\
\hline 0 & $3.58 \pm 0.27 \mathrm{e}$ & $3.07 \pm 0.15^{\mathrm{d}}$ & $6.49 \pm 0.08^{\mathrm{c}}$ & $4.48 \pm 0.07^{\mathrm{e}}$ & $\mathrm{B}^{+}$ & Good \\
10 & $5.37 \pm 0.21^{\mathrm{d}}$ & $5.87 \pm 0.15^{\mathrm{c}}$ & $7.10 \pm 0.1^{\mathrm{b}}$ & $6.51 \pm 0.08^{\mathrm{d}}$ & $\mathrm{A}$ & Very good \\
15 & $6.22 \pm 0.12^{\mathrm{c}}$ & $6.13 \pm 0.06^{\mathrm{c}}$ & $8.37 \pm 0.2^{\mathrm{a}}$ & $7.03 \pm 0.15^{\mathrm{c}}$ & $\mathrm{A}$ & Very good \\
20 & $7.46 \pm 0.04^{\mathrm{b}}$ & $7.13 \pm 0.05^{\mathrm{b}}$ & $8.28 \pm 0.02^{\mathrm{a}}$ & $8.15 \pm 0.05^{\mathrm{b}}$ & $\mathrm{A}^{+}$ & Very good \\
25 & $8.35 \pm 0.05^{\mathrm{a}}$ & $8.17 \pm 0.38^{\mathrm{a}}$ & $8.41 \pm 0.03^{\mathrm{a}}$ & $8.87 \pm 0.15^{\mathrm{a}}$ & $\mathrm{A}^{+}$ & Very good \\
\hline
\end{tabular}

$1 \mathrm{~S} / \mathrm{F}=$ Softness/firmness; $\mathrm{C} / \mathrm{R}=$ Chewiness/rubberiness; FT = Folding test; GA = General appearance

* Each value is mean \pm Standard deviation of triplicate determinations

* Data bearing different superscripts in the same column differ significantly $(\mathrm{P}<0.05)$

\section{Evaluation of the shelf life of the burger}

The changes in colour, odour, taste, texture and general appearance of pangus burger stored at room $\left(28^{\circ} \mathrm{C}\right)$ and refrigerated temperature $\left(5^{\circ} \mathrm{C}\right)$ are shown in Table 6 . All the sensory attributes were decreased with the progress of storage period $(\mathrm{P}<0.05)$ at room temperature. The initial prominent fresh sweet odour of fish burger became gradually pungent followed by a sour odour accompanied by moist slimy surface with fungal growth at 72 hours $28^{\circ} \mathrm{C}$, which was indicative of large bacterial growth. Bad smell observed at 48 hours of storage time and fungal growth was visible at the storage time of 72 hours. Although a slight pungent odour was felt at 24 hours. According to the statistical analysis, there was no significant differences $(\mathrm{P}>0.05)$ in colour, odour and 
texture between 0 hour to 24 hours of storage period with exception of taste and general appearance properties.

Table 6. Effect of the storage temperature on sensory quality attributes of fish burger prepared from pangus fish mince (The description of the sensory scores is mentioned in materials and methods under the section shelflife analysis and sub section sensory evaluation)

\begin{tabular}{c|c|c|c|c|c|c}
\hline $\begin{array}{c}\text { Storage } \\
\text { temperature }(\mathrm{oC})\end{array}$ & $\begin{array}{c}\text { Storage period } \\
(\mathrm{hr})\end{array}$ & Colour & Odour & Taste & Texture & $\begin{array}{c}\text { General } \\
\text { appearance }\end{array}$ \\
\hline 28 & 0 & $9.00 \pm 0.00^{\mathrm{a}}$ & $9.00 \pm 0.00^{\mathrm{a}}$ & $9.00 \pm 0.00^{\mathrm{a}}$ & $8.93 \pm 0.12^{\mathrm{a}}$ & $8.97 \pm 0.05^{\mathrm{a}}$ \\
& 24 & $8.9 \pm 0.036^{\mathrm{a}}$ & $8.67 \pm 0.11^{\mathrm{a}}$ & $8.17 \pm 0.17 \mathrm{~b}$ & $8.43 \pm 0.10^{\mathrm{a}}$ & $8.43 \pm 0.10^{\mathrm{b}}$ \\
& 48 & $4.93 \pm 0.10^{\mathrm{b}}$ & $2.26 \pm 0.45^{\mathrm{b}}$ & $2.90 \pm 0.36^{\mathrm{c}}$ & $2.67 \pm 0.76^{\mathrm{b}}$ & $3.40 \pm 0.36^{\mathrm{c}}$ \\
5 & 72 & $1.26 \pm 0.21^{\mathrm{c}}$ & $1.25 \pm 0.25^{\mathrm{c}}$ & $1.00 \pm 0.00^{\mathrm{d}}$ & $1.43 \pm 0.25^{\mathrm{c}}$ & $1.00 \pm 0.00^{\mathrm{d}}$ \\
& 0 & $9.00 \pm 0.00^{\mathrm{a}}$ & $9.00 \pm 0.00^{\mathrm{a}}$ & $9.00 \pm 0.00^{\mathrm{a}}$ & $8.93 \pm 0.12^{\mathrm{a}}$ & $9.00 \pm 0.00^{\mathrm{a}}$ \\
& 24 & $8.67 \pm 0.33^{\mathrm{a}}$ & $8.83 \pm 0.41^{\mathrm{a}}$ & $8.73 \pm 0.32^{\mathrm{a}}$ & $8.5 \pm 0.55^{\mathrm{a}}$ & $8.95 \pm 0.33^{\mathrm{a}}$ \\
& 48 & $8.50 \pm 0.50^{\mathrm{a}}$ & $8.78 \pm 0.42^{\mathrm{a}}$ & $8.68 \pm 0.36^{\mathrm{a}}$ & $7.78 \pm 0.19^{\mathrm{b}}$ & $8.70 \pm 0.32^{\mathrm{a}}$ \\
& 72 & $8.42 \pm 0.49^{\mathrm{a}}$ & $8.09 \pm 0.17^{\mathrm{b}}$ & $8.46 \pm 0.63^{\mathrm{a}}$ & $6.80 \pm 0.26^{\mathrm{c}}$ & $8.6 \pm 0.40^{\mathrm{a}}$ \\
\hline
\end{tabular}

* Each value is mean \pm standard deviation of triplicate determinations

* Data bearing different superscripts in the same column differ significantly $(\mathrm{P}<0.05)$

On the other hand, at refrigerated temperature $\left(5^{\circ} \mathrm{C}\right)$ the product was more stable. The colour, taste and general appearance did not changed markedly even after 72 hours $(\mathrm{P}>0.05)$. A slight pungent odour felt at 72 hours but it was not considered as unacceptable. Fungal growth also not present after 72 hours. The textural quality changed significantly $(\mathrm{P}<0.05)$ at 48 and 72 hours but also considered as acceptable. The results of this study are in accordance with the results of Shammi (2005).

The TVB-N value increased progressively through out the storage period $(\mathrm{P}<0.05)$ at both room $\left(28^{\circ} \mathrm{C}\right)$ and refrigerated $\left(5^{\circ} \mathrm{C}\right)$ temperature (Table. 7$)$. But in case of room temperature, the increase was very rapid than the refrigerated temperature. At room temperature, the TVB-N value was higher than the all acceptable limits reported by different researchers at 48 hours and the value was $28.81 \mathrm{mg} / 100 \mathrm{~g}$. At 72 hours the value reached to $37.28 \mathrm{mg} / 100 \mathrm{~g}$, which indicate that the product is completely spoiled. The acceptability limits of TVB-N were reported at $30 \mathrm{mg} / 100 \mathrm{~g}$ meat for silver carp (Hypophthalmichthys molitrix) by Siddaiah et al. (2001) and 18 and $24 \mathrm{mg} / 100 \mathrm{~g}$ meat for stored pink perch (Nemipterus japonicus) mince by Reddy et al. (1995). Al-Kahtani et al. (1996) reported that this acceptability limit was $19.5 \mathrm{mg}$ TVB-N/100 $\mathrm{g}$ for tilapia and 25.2 mg TVB-N/100g for Spanish mackerel (Scomberomorus maculatus).

On the other hand, at refrigerated temperature the values were lower than the all acceptable limits even at 72 hours and the value was $18.56 \mathrm{mg} / 100 \mathrm{~g}$.

The changes in bacterial load $(\mathrm{CFU} / \mathrm{g})$ of pangus burger in both room $\left(28^{\circ} \mathrm{C}\right)$ and refrigerated temperature $\left(5^{\circ} \mathrm{C}\right)$ are shown in Table 8 . In both temperatures, the APC 
(Aerobic Plate Count) was increased through out the storage period $(\mathrm{P}<0.05)$. Initial bacterial load of fish burger prepared from pangus fish mince was $1.58 \times 10^{4} \mathrm{CFU} / \mathrm{g}$. Bacterial growth in fish burger kept at room temperature rapidly increased $(\mathrm{P}<0.05)$ with the progress of storage time and within 24 hours APC increased to $8.2 \times 10^{6} \mathrm{CFU} / \mathrm{g}$, after 72 hours these values reached to $3.1 \times 10^{9} \mathrm{CFU} / \mathrm{g}$.

Table 7. Effect of the storage period on TVB-N value of fish burger prepared from pangus fish stored at different storage temperature

\begin{tabular}{ccc}
\hline Storage period $(\mathrm{hr})$ & Room temperature $\left(28^{\circ} \mathrm{C}\right)$ & Refrigeration temperature $\left(5^{\circ} \mathrm{C}\right)$ \\
\hline 0 & $6.38 \pm 0.13^{\mathrm{d}}$ & $6.38 \pm 0.13^{\mathrm{d}}$ \\
24 & $17.33 \pm 0.39^{\mathrm{c}}$ & $8.56 \pm 0.53^{\mathrm{c}}$ \\
48 & $28.81 \pm 0.23^{\mathrm{b}}$ & $12.25 \pm 1.13^{\mathrm{b}}$ \\
72 & $37.28 \pm 1.09^{\mathrm{a}}$ & $18.56 \pm 0.59^{\mathrm{a}}$ \\
\hline
\end{tabular}

* Each value is mean \pm Standard deviation of triplicate determinations

* Data bearing different superscripts in the same column differ significantly $(\mathrm{P}<0.05)$

Table 8. Effect of the storage period on bacterial load of fish burger prepared from pangus fish stored at different storage temperature

\begin{tabular}{c|c|c|c|c}
\hline \multirow{2}{*}{ Product } & \multirow{2}{*}{$\begin{array}{c}\text { Storage } \\
\text { temperature }\end{array}$} & $\begin{array}{c}\text { Storage time } \\
\text { (hours) }\end{array}$ & \multicolumn{2}{|c}{ Bacterial load } \\
\cline { 4 - 5 } & & 0 & $\mathrm{CFU} / \mathrm{g}$ & $\mathrm{Log} \mathrm{CFU} / \mathrm{g}$ \\
\hline Fish burger & $28^{\circ} \mathrm{C}$ & 24 & $8.58 \times 10_{4}$ & $4.20 \pm 0.19 \mathrm{~d}$ \\
& & 48 & $2.3 \times 10_{6}$ & $6.91 \pm 0.51^{\mathrm{c}}$ \\
& 72 & $5.9 \times 10_{9}$ & $8.36 \pm 0.12^{\mathrm{b}}$ \\
& & 0 & $1.58 \times 10_{4}$ & $9.77 \pm 0.23^{\mathrm{a}}$ \\
\cline { 3 - 5 } & $5^{\circ} \mathrm{C}$ & $5.93 \times 10_{4}$ & $4.20 \pm 0.19 \mathrm{~d}$ \\
& 48 & $2.3 \times 10_{5}$ & $4.77 \pm 0.11^{\mathrm{c}}$ \\
& 72 & $2.1 \times 10_{7}$ & $5.36 \pm 0.14^{\mathrm{b}}$ \\
& & & $7.32 \pm 0.49^{\mathrm{a}}$ \\
\hline
\end{tabular}

* Each value is mean \pm Standard deviation of triplicate determinations

* Data bearing different superscripts in the same column differ significantly $(\mathrm{P}<0.05)$

On the other hand, same fish burgers kept at refrigeration temperature the bacterial growth pattern was somewhat different. In this case, rate of bacterial growth was slower and during the 24 hours storage time no big change were observed in APC, after that bacterial growth gradually increased $(\mathrm{P}<0.05)$ and after 72 hours the APC reached to $2.1 \times$ $10^{7} \mathrm{CFU} / \mathrm{g}$ in fish burger. Neither bad smell nor fungal growths were apparent in the product during that period (Shammi, 2005).

\section{ACKNOWLEDGEMENT}

The authors are grateful to Ministry of Science and Information \& Communication Technology for financial support to this research project. 


\section{REFERENCES}

AOAC. 1984. "Official Methods of Analysis." 14th edn. Association of Official Analytical Chemists, Washington DC, USA.

AOAC. 1990. "Official Methods of Analysis." 15th edn. Association of Official Analytical Chemists, Washington DC, USA.

Azad, A. K. 2001. Formulation and Development of Fish Burger and Fish Stick from Silver Carp and Their Quality Evaluation. M. S. Thesis, Department of Fisheries Technology, Bangladesh Agricultural University, Mymensingh, Bangladesh.

Barraw, G. L. and Feltham, R. K. A. (Ed.). 1993. Cown and Steet's Manual for the Identification of Medical Bacteria, Edn. 2. Cambridge University Press.

Bligh, E. G. and Dyer, W. J. 1959. A Rapid Method of Total Lipid Extraction and Purification. Can. J. Biochem. Phys., 37: 911-917.

Edwards and Kaewpaitoon. 1981. “Fish Farming with Livestock Manure'. Paper presented at a seminar on maximum livestock production from minimum land, jointly organized by the Department of Animal Science, BAU, NYRDP-DANIDA, Bangladesh Agricultural University, Mymensingh, 2-5 February, 1981.

Ihm, C. W., Kim, J. S., Joo, D. S. and Lee, H. E. 1992a. Processing and Quality Stability of Precooked Frozen Fish Foods: (I) Processing of Sardine Burger. Hanquk Nonghwakak Hoechi. (J. Korean Agric. Chem. Soc.), 34(4): 254-259.

Ihm, C. W., Kim, J. S., Joo, D. S. and Lee, H. E. 1992b. Processing and Quality Stability of Precooked Frozen Fish Foods: (II) Processing of Sardine Burger. Hanquk Nonghwakak Hoechi. J. Korean Agric. Chem. Soc., 35(4): 260-264.

Ludorff, W. and Meyer, V. 1973. Fische und Fischerzeugnisse. Paul Parey Verlag, Hamburg- Berlin.

Nowsad, A. A. 1994. Raw material for the manufacture of surimi - II. The Bangladesh Observer, March 8 and 9, 1994, Dhaka, Bangladesh.

Nowsad, A. A., Kanoh, S., Chanda, S. C. and Niwa, E. 2000c. Gel forming ability and other properties of eleven underutilized tropical marine fish species. Journal of Aquatic Food Product Technology, 9(3): 71-75.

Nowsad, A. K. M. 2004. Development of value added products from by-catch and under utilized fisheries organisms and pilot marketed testing of product acceptability among rural communities. Final report, Support for Universities Fisheries Research and Education (SUFER) Projects.

Paulus, K., Zacharias, R., Robinson, L. and Geidel, H. 1979. Kritische Betrachtungen zur "Bewertenden Prüfung mit Skale" als Einem Wesentlichen Verfahren der Sensorichen Analyse. Lebensm Wiss Technicol., 12: 52-61.

Shammi, S. S. 2005. Development of Value Added Products from Underutilized Queen Fish. M. S. Thesis, Department of Fisheries Technology, Bangladesh Agricultural University, Mymensingh, Bangladesh. 